\title{
Erratum to: Model of Cation Transportation Mediated by High-Affinity Potassium Transporters (HKTs) in Higher Plants
}

Yi Su, ${ }^{1,2^{*}}$, Weigui Luo ${ }^{1}$, Wanhuang Lin ${ }^{1,2}$, Liying $\mathrm{Ma}^{3}$ and Mohammed Humayun Kabir ${ }^{1}$

\section{Erratum}

After publication of this work [1], it has come to our attention that Mohammed Humayun Kabir's name was displayed incorrectly. The full list of authors has now been updated. We are publishing this erratum to update the author list, which is as follows:

Yi Su, Weigui Luo, Wanhuang Lin, Liying Ma and Mohammed Humayun Kabir.

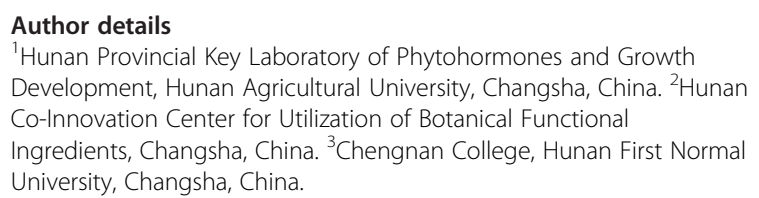

Received: 17 March 2015 Accepted: 25 March 2015

Published online: 30 April 2015

\section{Reference}

1. Su Y, Luo W, Lin W, Ma L, Kabir MH. Model of Cation Transportation

Mediated by High-Affinity Potassium Transporters (HKTs) in Higher Plants.

Biol Proced Online. 2015;17:1.

\footnotetext{
*Correspondence: hunausy@163.com

'Hunan Provincial Key Laboratory of Phytohormones and Growth

Development, Hunan Agricultural University, Changsha, China

${ }^{2}$ Hunan Co-Innovation Center for Utilization of Botanical Functional

Ingredients, Changsha, China

Full list of author information is available at the end of the article
}

Submit your next manuscript to BioMed Central and take full advantage of:

- Convenient online submission

- Thorough peer review

- No space constraints or color figure charges

- Immediate publication on acceptance

- Inclusion in PubMed, CAS, Scopus and Google Scholar

- Research which is freely available for redistribution

Submit your manuscript at

www.biomedcentral.com/submit

( Biomed Central 